\title{
META-ANALYSIS ON BITCOIN
}

\section{SAMER AJOUR EL ZEIN ${ }^{1}$, CARLOS ROMERA JIMÉNEZ, REZA GHESHMI}

Economics and Business Administration Department, EAE Business School, Spain

The reason of this work is due to the lack of a publication that summarizes and unifies the main contributions that have been made during the last decade. The main objective of this work is the exhaustive literature review of Bitcoin. This study proposes to pursue the understanding of this technology and its environment in a simple, summarized way and based on a large amount of research work, bibliometric analysis, and scientific articles, to unify the studies of this new concept.

The variables studied in this work include cryptocurrencies, specifically Bitcoin, its history, its technology and its operation, its legislative framework in the world and in Spain, its operation and application to society, and the possibility of a price bubble we well as its advantages and disadvantages.

The main contributions to the literature include both theoretical and methodological aspects, as well as considerations about Bitcoin, their application and behavioral factors. The results provide reasons for professionals to improve their business models in the application of this technology and, in addition, help scientists to take the initiative to continue researching more adequately.
\end{abstract}

KEYWORDS: Meta-Analysis, Bitcoin, Blockchain

Received: Jun 08, 2020; Accepted: Jun 28, 2020; Published: Sep 08, 2020; Paper Id.: IJMPERDJUN20201117

\section{INTRODUCTION}

A virtual currency is that innovative payment instrument (Fabozzi, \& Frank, 2019), which represents a value, lacks a physical backing (Briere, Oosterlinck, \& Ariane Szafarz, 2015) and issuer (Haggard, Maxfield, \& Lee, 2019), but it is accepted by natural and legal persons (Yuzvovich, Isakova, \&Mokeeva, 2019).

However, the project that marked a before and after, and is the subject of study of this work, is Bitcoin. It is based on the revolutionary technology called Blockchain, defined as a distributed and secure database that contains a record of all the transactions that have taken place on the network (Deloitte, 2018).

ICOs (Initial Coin Offering) (Frankerfiled, 2019) arise to finance cryptocurrency projects. Thanks to these, and the open source of Bitcoin (Gronwald, 2019), other cryptocurrencies such as Etherum, Litecoin and Ripple have emerged to generate competition for Bitcoin and bring innovation to the market.Bitcoin arises in response to the 2008 crisis (Kostakis, \&Giotitsas, 2014), where Satoshi Nakamoto published the Whitepaper giving rise to its origin. From here, 12 years of history surround him, going through various stages throughout his short life.The two main storage routes are through cold and hot wallets (Macho, 2019). Once stored, they can be 
used for transactions, where those known as "miners", which can be anyone with a computer, are responsible for validating your transaction in exchange for remuneration (Pérez, \& Herrera, 2014).

Bitcoin solves such important problems as double spending (Ramos, 2014) and counterfeiting (Rosales, Reyes, Gallegos, 2017) and in 2018 it had a total of 7.1 million active users (Chain analysis, 2018). Despite having been solving problems during these years, Bitcoin continues to be a very new technology, which entails a legislative problem around the world, questioning its nature (McLeod, 2017)

Advantages like its integrity, its security and its efficiency rise as part of its strength. Disadvantages such as its volatility, anonymity and legislative framework seriously threaten the viability of this project and therefore the survival of Bitcoin. The main objective of this work is the exhaustive literary review of Bitcoin. The understanding of this technology and its environment is pursued in a simple, summarized and based on a large amount of research work, bibliometric analysis and scientific articles to unify the studies of this new concept.

\section{Virtual Currency}

We call any instrument currency (Howlett, 2019), unconditionally accepted in the market where it operates, which serves to exchange goods and services, to settle accounts (Pallares, 2014).

After entering the definition of currency, we define virtual currency as:

Heterogeneous set of innovative payment instruments (Fabozzi, \& Frank, 2019) with a representation of value that, by definition, lacks physical support to back them up (Briere, Oosterlinck, \& Ariane Szafarz, 2015), not issued by a central bank or public authority (Haggard, Maxfield, \& Lee, 2019), accepted by natural and legal persons as a means of payment (Yuzvovich, Isakova, \& Mokeeva, 2019) and that can be stored or exchanged electronically (European Banking Authority, 2014).

These become increasingly important, booming in markets such as online games (Cotte, \& Kathryn, 2009), turning out to be an alternative payment solution and better adapted to the particular needs of the exchange of virtual goods and services (Nayfack, 2019 ). Despite the large number of cryptocurrency varieties that we have today (Martín, 2019), the market's attention is mainly focused on a successful initiative on a global scale (Nawaz, Zoraiz, et al., 2019) and on which this research work is based, Bitcoin (Gorjón, 2014).

Even so, there are more than 2,500 cryptocurrencies on the market, despite the fact that the ones that are significant, that is, with profit, are around 20:30. In TOP 3 we find Bitcoin, Etherum and Ripple XPR (Plus500, 2020).

\section{Bitcoin}

Recent years have been a steady career in the field of technology (Sánchez, 2017), thus affecting all activities of our daily lives, and, of course, revolutionizing payment methods (PWC, 2020). You only need to see the large increase in online purchases and the amount of telematics payments today compared to a few years ago (Sanjuán, \& Costa, 2019).However, payment solutions have not evolved as quickly, which is why Bitcoin is considered a possible option for the evolution of the monetary field (Segendorf, 2014).According to the Whitepaper "Bitcoin: A Peer-to-Peer Electronic Cash System" of its creator, Satoshi Nakamoto, Bitcoin is defined as:

"A purely electronic version of cash that will allow online payments sent directly from one entity to another without having to go through a financial institution." 
It is based on Blockchain technology, defined as a distributed and secure database that contains a record of all transactions and operations that have occurred within the network (Deloitte, 2018).

It contains various features, including:

"peer-to-peer" system (P2P), consisting of non-intervention of any intermediary who can control or track transactions, designed for anonymous payments (Schollmeier, 2001).It works as a transaction ledger (Gupta, Bansal, \&Porwal, 2019), distributed among users, who keep a copy updated in real time (Argañaraz, Mazzuchelli, Albanese, \& López, 2019). Being decentralized, the custody function belongs to those who participate in the network (Rabasa, 2017). Therefore, for the acceptance of a change, every user must agree with it, and once accepted, it is added and cannot be altered or destroyed. (Zapiola, 2019)

- Authenticate, verify, and without borders. It enables secure transactions and property verification in addition to providing a quick and cheaper infrastructure for the exchange of value units (Gómez, Castro, Presidente, Malagón, Técnico, Montoya, \& Sánchez, 2017).

- Standard protocol, defining a common standard in communication between the main computers on the network (Preukschat, 2016).

- Bitcoin uses cryptography, considered a discipline / technology aimed at solving problems of authenticity and confidentiality (Marrero, 2003), which provides the ideal tools for Bitcoin to be used as a security measure (Pallares, 2014).

\section{Altcoins}

Altcoin comes from the words "alternative" and "coin". It is used to refer to alternative cryptocurrencies to Bitcoin. Due to the success of this, they are coins that have emerged (Gronwald, 2019) thanks to their open source and part of them are known as "forks" of Bitcoins, or ramifications in Spanish (Marco, 2017).Altcoins are bitcoin-like currencies, many of them based on their open source, they pursue different objectives and provide new modifications, different algorithms, mining methods... (Cámara, 2018). They cover changes from something merely aesthetic to changes in their algorithms (Oroy Finanazas, 2014). They intend to include or provide technical details that Bitcoin did not incorporate at the time, trying to improve its functionalities (Marco, 2017).Thanks to Altcoins, a competition faces Bitcoin and is not counterproductive, on the contrary, they benefit from each other, encompassing innovation thanks to said competition (Bit2me, 2020).

Three Altcoins are discussed below with relevance for different reasons today.

\section{Ethereum}

Etherum is a decentralized software platform, with ether as cryptocurrency, where "Smart Contracts" and "Descentralized Applications" (DApps) are allowed (Reiff, 2020), two very important and revolutionary features that we will define below:

Smart Contracts: This technology consists in that every transaction will be carried out if it meets the conditions established in the contract (De Biase, \& Mayor, 2017). A Smart Contract refers to one that runs by itself without any intervention and is written as a computer program instead of using a legal document (Espinosa, 2016).

DApps: Etherum has developed its coding language, Solidity (similar to JavScript), which allows DApps to be developed (Antonopoulos, \& Wood, 2018). As their name indicates, they are decentralized applications that use Blockchain, in order 
to make users relate to each other and there is no central entity that manages the service. (BBVA, 2018). These must meet various requirements such as having open source, operating autonomously, and generating tokens according to the algorithm... (Johnston, Yilmaz, Kandah, Bentenitis, Hashemi, Gross,\& Mason, 2014).

With this, it intends to establish an entire network (Almarcha, 2017), pursuing the objective of carrying out a large number of activities, such as transactions or applications, through the ether currency and the use of Blockchain (Miranda, 2018).

\section{Litecoin}

Created by the former Google employee and Director of Engineering at Coinbase, Charile Lee (Knight, 2020), it stands out against Bitcoin in the average transaction validation time, which stands at 2.5 minutes, unlike the 10 it requires Bitcoin (Su, 2018).

Unlike Bitcoin, it uses another logarithm called Scrypt (Watkins, 2017). This algorithm change causes mining to change and makes it easier to solve its problems, appreciated in its short validation time for each transaction (Medina, 2016). Thanks to this, it opens access to teams with fewer resources to carry out this activity (Hileman, Garrick \&Rauchs, Michel, 2017). It also differs in its monetary mass, being 84 million, compared to 21 for Bitcoin (García, 2016).

\section{Ripple}

It is the protocol that banks intend to acquire to make transactions taking advantage of Blockchain technology (Ripple, 2020). This would make Ripple a centralized currency, managed by institutions such as Banco Santander (Cointelegraph, 2020).

Therefore, it is a matter of controversy, since, on the one hand, cryptocurrencies are based on a decentralized technology without intermediaries or third parties, and however, the main drivers of this to date are various banks (Cabanes, 2017).Ripple uses an algorithm that requires that any computer that wishes to connect to the network, first identify itself and then obtain permission to participate in it, unlike Bitcoin, any computer can enter its network without needing to identify itself (Castro, Fumero,\& González, 2018).

It is important to re-emphasize that Ripple pursues the use of Blockchain technology to allow financial institutions to send money instantly, safely, regardless of borders and at minimal cost to the user (Ripple, 2020).

\section{Bitcoin}

\section{History of Bitcoin}

The origin of Bitcoin comes as a response to the crisis of 2008 (Kostakis, \&Giotitsas, 2014), when the global economic crisis and the recession cast doubt on the financial and monetary paradigm (Vargas, \& Díaz, 2016) and the reliability of the intermediaries and institutions that were part of the market (Oregaen, Fabiana, Priori, \&Ruzak, 2014). When the time came, Satoshi Nakamoto published a document with the title: "Bitcoin: A Peer-to-Peer Electronic Cash System", (Nakamoto, 2008). This describes a technology that consists of a decentralized network, with its own currency, capable of making payments safely, without the need for third parties such as financial or government institutions (Nakamoto, 2008). With this, it focuses the supervision and control of the Bitcoin network on the users themselves (Cámara, 2018). In August 2008, the official website of the currency is registered: Bitcoin.org and the issuance of bitcoins begins (Chohan, 2017a, 2017b, 2017c, 2017d, 2017e). 
The first block of bitcoins was mined on January 3, 2009, mined by Nakamoto with a total of 50 bitcoins, known as the "Genesis Block" (Tejada, 2014). After its launch, Nakamoto mined an approximate amount of 1 million bitcoins just before disappearing and ceasing to be involved in the Bitcoin movement (Cárdenas, Avellaneda, \&Bermúdez, 2015), not before, along with Hal Finney, carry out the first Bitcoin transfer in history (Díaz, 2020).

In 2010, when a Florida programmer, Laszlo Hanyecz (Oregaen, Fabiana, Priori, \&Ruzak, 2014), made the first transaction after buying two pizzas at Papa John's worth 10,000 bitcoins (Newcomb, 2014). The first Bitcoin market, Mt. Gox (Frankenfield, 2020) is created and parity with the dollar is reached (RicaurteCely, \& Romero, 2018). In this same year, the SilkRoad page (Ricaurte, \& Romero, 2018) was founded, where, through bitcoins, the largest sale and purchase of narcotic substances over the internet was made (Hume, 2013).

In 2012, the global Bitcoin service BitPay, a payment processor, confirmed the acceptance of Bitcoin as a currency in more than 1,000 merchants (Browdie, 2012).

In 2013, Coinbase, another payment processor, announced that it had sold $\$ 1$ million in bitcoins in one month (Ludwig, 2013). Bitcoin enters the mouth of many government entities due to the increase in its volume, surpassing Western Union (History of Bitcoin, 2014).

The American Network for the Suppression of Financial Crimes (FinCEN) first established regulatory standards for electronic currencies, including Bitcoin among them (Fonseca, Santiago, \& Amorín, 2019). They were categorized as "Money Service Business", subject to legal obligations. Failure to comply with these would cause the immediate closure of all accounts related to the virtual currency in question (FinCEN, 2013). To all this, the disparity of responses against cryptocurrencies was reflected in the world panorama (Riquelme, 2017), taking them to the field of confusion and legislative conflicts (Gutiérrez, \& Moreno, 2017). Examples such as the case of Thailand, which became the first country not to accept Bitcoin due to the lack of applicable legislation (BBC, 2013). Others such as federal judge Amos Mazzant, of the Eastern District of Texas, who considered Bitcoin as "a currency or form of money" under Federal Securities Laws and, therefore, are valid and subject to such legislation (Hill, 2013).

In October 2013, the FBI closes Silk Road, where the owner of the page, Ross William Ulbritch, is arrested on charges of narcotics trafficking, conspiracy and money laundering (Reuters, 2013). Meanwhile, China becomes the largest bitcoin exchange point (Chohan, 2017), where the Central Bank of China prohibits financial institutions from trading Bitcoin, causing a drop in its prices (Suárez, \& Bautista, 2016). This same year the first Bitcoin ATM in Vancouver is created (Wagner, 2013).

In 2014, an even larger assortment of businesses began accepting Bitcoin, including the Las Vegas and Microsoft casinos. Furthermore, Bitcoin-based derivative products arose when the Tera Exchange received the go-ahead from the US government to market a product which its underlying asset was the price of Bitcoin (Chohan, 2017). There were also cases of cyber-attacks such as that of Mt. Gox, victim of a robbery of 744,000 bitcoins causing its bankruptcy (The Guardian, 2011), or that of Bitfinex, with a total theft of 120,000 bitcoins (Europa Press, 2016).

In 2015 New York implemented the first regulation for the exchange of digital currency, the "Bit License" (New York Press, 2015).

In March 2016, the Japanese government recognized that virtual currencies had a function similar to that of real money, legalizing it later in 2017 as a means of payment (EFE, 2016). In Argentina, Uber started accepting payments in 
bitcoins (Redman, 2016).

In 2017, Bitcoin is affected by the large Bitcoin Cash (BTH) hard fork (Reiff, 2020).

During recent years the momentum of Bitcoin has been maintained and now it is found in diverse niches such as in B2B supply chains (Tan, \& Low, 2017), consumer services, derivatives (Finance, 2020) and many others. Furthermore, more and more countries are legalizing Bitcoin as a form of payment, as is the case with Norway's largest Bank, Skandiabanken, which started integrating bitcoin accounts in 2017 (Lielacher, 2017).

Finally, regarding its price, it has continued with high volatilities, which is why it favored the Bitcon Cash hard fork (Álvarez-Díaz, 2019).

\section{Bitcoin Operations}

\section{Bitcoin Storage}

Virtual space that is equivalent to a physical wallet where you can store and make payments with cryptocurrencies (García, 2016).Wallets, as a general rule, have a public and a private key for the use of this and that makes you the owner of the bitcoins that are in it (Carrillo, 2019). The two main ways to store bitcoins are cold and hot wallets (Macho, 2019).

\section{Hot Wallets}

Virtual wallet permanently connected to the Bitcoin network (Astray, 2019). It allows the user to access it remotely, with any device that has an internet connection and are considered easier to operate (Macho, 2019).It is recommended for transactions in which assets need to be moved quickly, but it is advisable not to have large amounts Being connected to the internet (Covarrubias, J., \& Covarrubias, I. 2019), he is exposed to a possible cyber-attack, being more risky than hot ones (Alonso, 2019). Examples like Coinbase, Blockchain, CoinSpot and many others do this function (BrokerOnline, 2020).Carterasfrías

The most recommended in the case of storing a large number of assets, since they are not connected to the network. It is only connected for the purpose of making a transaction and then disconnect again (Covarrubias, J., \& Covarrubias, I., 2019).

\section{Hardware}

Mostly USB devices or external hard drives, they usually have a pin to access them and through the software they have installed, they contain cryptocurrencies (Alonso, 2019). Examples such as Ledger or Trezor are among the most recommended (Falk, 2020).

\section{Paper Wallet}

It consists of a physical paper with a QR code that the cryptocurrency has (Tostado, González, Burgueño, \& Ramírez, 2017).

- Desktop: Bitcoins downloaded on a single device and you can only access them through that specific computer (Bayés, 2019)

\section{Mining}

A bitcoin is technically created out of nothing (Gutiérrez, 2015). They are produced by algorithm-based software, where 
cryptographic problems are solved (Wander, 2011), leading to the creation of these to be distributed among users, which facilitate the processing and validation of information (Castro, Mora, \&Neira, 2019).

However, the main objective pursued by mining is not the creation of a monetary mass (Caballero, 2018).

If we think about the concept of miners, they are those who, through machinery, extract gold or other precious metals from a mine to obtain profit (Forero, \& Sanabria de Luque, 2017). Bitcoin works in a similar way, the difference is that instead of using heavy machines, computer equipment is used to perform very complex mathematical calculations and in return they are rewarded with remuneration (Wander, 2011).

Figure 4 shows the oscillation of the average cost per transaction in dollars during the months of March and April 2020. These are low, currently at a total of 0.63 USD / Transaction (Blockchain, 2020). The purpose of the commissions today is to increase the validation speed to be more attractive to miners (Sevilleja, 2013), so there are transactions that do not have to have any commission (Caballero, 2018).

The bitcoin mining process always consists of the same process (Bit2me, 2020). Miners receive a mathematical problem every ten minutes (Wander, 2011) and the fastest will be the remuneration in the form of newly created Bitcoins (Boar, 2018), as long as the answer is correct and validated by the other members of the network (Conti, 2017).

To be part of the network and be a miner, you only have to download the Bitcoin client (Gutiérrez, 2015). This program connects your computer to the network and turns it into one more node of the network, in order to verify and issue new transactions (Retamal, Roig, \& Tapia, 2017).

\section{The Effect of "Halving"}

The rewards miners have received over the years have been declining, and this is where the Halving concept comes in (Duffield, \& Hagan, 2014). It consists of the reduction of the benefit for validating a block, specifically 50\%, pursuing the purpose of controlling the money supply (Meynkhard, 2019), based on a deflationary model (Herman, 2014). Every 210,000 mined blocks (previously established), the number of bitcoins released will be reduced by 50\% (Conti, 2017).

In the table we see the Halvings that have already been and a forecast of those to come (IG, 2020) (the closest, after these there will be more). The first blocks were awarded with a total of 50 BTC, while today they are awarded with 12.5 BTC (Rosenfeld, 2017), and waiting this year for next Halving, cutting it to a total of 6.25 BTC ( Port, 2020).

\section{Mining Pools}

The increased difficulty of these mathematical problems (Asensio, 2014) affects an increase in necessary energy and more powerful hardware (Conti, 2017) for mining, together with the gradual reduction of the benefit from mining, seen in the Halving Effect, have Alternatives have emerged to make the process beneficial (Lane, 2018).

As a solution to this, miners have found a solution, join a mining pool (Sevilleja, 2013), where many individuals (Johnson, Laszka, Grossklags, Vasek, \& Moore, 2014), without needing to know each other (Saravia, Javiel, \& Paredes, 2018), add the powers of their devices for collective work (Konoth, Vineti, Moonsamy, Lindorfer, Kruegel, Bos, \& Vigna, 2018). The benefits, as a general rule, will be distributed proportionally to the power that each user has contributed to the mining pool (Frankenfield, 2019).

The exact number of computers attached to the network is very difficult to calculate, but according to a Quora 
user, based on the performance of May 2019, I calculate that there are around 3,800,000 machines involved around the world (Bitpanda, 2019).

\section{How does a Transaction Work}

Before making a transaction, both parties must have a place (wallet) to store the Bitcoin (Martin, \& Pons, 2019), already seen in a previous section, and bitcoins in it. When the transaction order is given, the public keys of the receiver, issuer and the amount are added (Carrillo, 2019). It is protected by a digital signature, it is sent to the public key of the recipient and is digitally signed by the sender's private key (Almarcha, 2017).

From this moment on, the transaction will be reflected in "The Chain of Blocks" (Cámara, 2018).

Each transaction can be monitored (Álvarez-Díaz, 2019) and is valid (Casares, 2019) by the miners (as it has been mentioned before, they will receive a remuneration based on their contribution in the network) and they must verify, through the Private and public keys, two factors before validating it:

- The one who makes the transaction is really the owner of those bitcoins (Canóvas, 2014).

- The owner has enough bitcoins in his account to face the transaction (Asensio, 2014).

All transactions must be validated by the nodes (Baraona, \& Najera, 2018), in order to be part of a block (Navarro, 2017).

However, each transaction has a time and goes through a series of nodes, so how do you ensure that nobody is spending the same bitcoins in another transaction? The problem of double spending arises here (Conesa, 2019).

\section{Bitcoin Today}

As of April 17, 2020 there is a total of 18,330,262.5 (87.287\%) total BTC mined, with an average of 1,800 new bitcoins per day and trading at a total of 7,055.45 Dollar / Bitcoin (Buy Bitcoins World Wide, 2020 ). The number of people who own bitcoins is estimated to be around 25 million (Madrid, 2019). In 2018 it was estimated that only a total of 7.1 million are active users of Bitcoin, among which 2.3 million use it as an exchange currency, while the other 4.8 use it for investment or speculative purposes (Chainalysis, 2018).

This high percentage of users who use the currency for speculation are the cause of their volatility being much higher than FIAT currencies (Zaera, 2014), thus creating one of the biggest problems facing the currency in terms of to its objective, to become a valid currency used by the public (Herrera, \& Hernández, 2018) and not as a speculative financial instrument (Dierckxsens, \& Formento, 2018).Daily transactions are around 279,707, a volume of \$ 256 million and a market capitalization of $\$ 128,445,910,104$ (Blockchain, 2020).

Bitcoin's legal framework in 2020 remains highly ambiguous (McLeod, 2017). Most developed countries such as the United States or the United Kingdom accept Bitcoin as legal (not therefore regulated at all) (Riquelme, 2017), while in emerging markets there is a lot of disparity, finding the example of India that banned in 2018, until very recently, March 2020, the commercialization of Bitcoin (Vaish Associates Advocates, 2020).However, tax law is where it is possible to find more contradictions depending on the country, since it is not clear whether it is considered money, property, financial asset... (Vergara Solís, 2017). Today, Bitcoin, in developed countries, is mainly considered as a property or financial asset rather than a currency. (Lesemann, 2020). 


\section{Bitcoin as a Speculative Bubble}

\section{Speculative Bubble}

A speculative, or economic, bubble is a situation in which there is an excessive and uncontrolled increase by an asset (Sánchez, 2020), creating a substantial and sustained deviation of its price from its fundamental value (García, 2017).

It is a process where buyers go wild to buy (Lemon, 2017) with the expectations of selling this product at a higher price in the future (Sánchez, 2020). Once it reaches the summit, due to different possible causes, the change in trend occurs and prices begin to slow down (Gamio, Marquez, Mesías, \&CastañedaLayseca, 2014). This leads to a downward spiral in prices where market agents panic, seeking liquidity for this asset in a market with very little demand and generating distrust around it (Gútierrez, 2020).

\section{CONCLUSIONS, LIMITATIONS AND FUTURE RESEARCH}

After carrying out the bibliometric analysis, and discovering a lack of unification of the criterion of this topic in the literature, the main conclusions of this meticulous literary review are to know the recent detailed discovery of the topic, along with the challenges that it entails.

This document is the starting point for a specific and detailed investigation of Bitcoin. It proposes to give a broader and simpler version of all that it entails. Thus, the objectives of this thesis have been met.The limitations of the study have been the insufficiency of recent quality documents for an adequate bibliometric analysis and the limitation of time, thus opening the opportunity for future research.

\section{Bibliometric Review Tables}

Table 1: Number of Articles and Research Papers Classified Per Year

\begin{tabular}{|c|c|}
\hline Año & Número de articulos y trabajos de investigación \\
\hline 2020 & 53 \\
\hline 2019 & 59 \\
\hline 2018 & 56 \\
\hline 2017 & 45 \\
\hline 2016 & 18 \\
\hline 2015 & 19 \\
\hline 2014 & 30 \\
\hline 2013 & 15 \\
\hline 2012 & 3 \\
\hline 2011 & 2 \\
\hline 2010 & 1 \\
\hline 2009 & 1 \\
\hline 2007 & 1 \\
\hline 2003 & 1 \\
\hline 2001 & 1 \\
\hline Total & 305 \\
\hline
\end{tabular}

Table 2: Outstanding Authors, Contribution to the Work and Year of its Publication 


\begin{tabular}{|c|c|c|}
\hline Autores & Concepto & Año \\
\hline Ammous, Saifedean. & Ventajas de Bitcoin & 2016 \\
\hline Bjerg, O. & Mineria & 2016 \\
\hline Böhme, R., Christin, N., Edelman, B., \& Moore, T. & Mineria & 2015 \\
\hline Chohan, U. W. & Historia de Bitcoin & 2017 \\
\hline England, C., \& Fratrik, C. & Bitcoin como contenedor de valor & 2018 \\
\hline Glaser, F., Zimmermann, K., Haferkorn, M., Weber, M. C., \& Siering, M. & Bitcoin como contenedor de valor & 2014 \\
\hline Hileman, Garrick \& Rauchs Michel. & Altcoins & 2017 \\
\hline Howlett, M. & Monedas virtual & 2019 \\
\hline Johnson, B., Laszka, A., Grossklags, J., Vasek, M., \& Moore, T. & Mining Pools & 2014 \\
\hline Kaplanov, N. M. & Bitcoin como moneda & 2012 \\
\hline Kostakis, V., \& Giotitsas, C. & Valor intrínsenco de Bitcoin & 2014 \\
\hline Krugman, P. R. & Bitcoin como unidad de cuenta & 2007 \\
\hline Kubát, M. & Bitcon como contenedor de valor & 2015 \\
\hline Ly, M. K. M. & Marco Legislativo & 2013 \\
\hline Nakamoto, $\mathrm{S}$. & Funcionamiento de Bitcoin & 2019 \\
\hline O'Dwyer, K. J., \& Malone, D. & Transacciones de Bitcoin & 2014 \\
\hline Schollmeier, R. & Tecnología Blockhain & 2001 \\
\hline Segendorf, B. & Ventajas de Bitcoin & 2014 \\
\hline Takaishi, T. & Precio de Bitcoin & 2018 \\
\hline Taylor, M. B. & Mineria & 2017 \\
\hline Turpin, J. B. & Legalidad & 2014 \\
\hline Woo, D. & Legalidad & 2013 \\
\hline Yermack & Bitcoin como moneda & 2015 \\
\hline
\end{tabular}

\section{REFERENCES}

1. Almarcha Navidad, C. (2017). Bitcoin, Oro electrónico.

2. Alonso Hernández, C. (2019). Blockchain y criptomonedas.

3. Antonopoulos, A. M., \& Wood, G. (2018). Mastering ethereum: building smart contracts and dapps. O'reilly Media.

4. Argañaraz, A., Mazzuchelli, A., Albanese, D., \& López, M. D. L. Á. (2019). Blockchain: un nuevo desafío para la contabilidad y auditoría. In XXV Encuentro Nacional de Investigadores Universitarios del Área Contable y XV Simposio Regional de Investigación Contable (La Plata, 12 de diciembre de 2019).

5. Asensio Grau, Y. (2014). Bitcoin: La nueva moneda virtual que está revolucionando el mundo de las divisas digitales.

6. Astray Rodríguez, M. C. (2019). Bitcoin ¿Oportunidad del siglo o burbuja especulativa?

7. BaraonaPohl, E., \&Najera Reyes, C. (2018). El peso de Bitcoin. ARQ (Santiago), (98), 32-43.

8. Bayés Capdevila, R. (2019). Estudio económico de la primera década del Bitcoin (2009-2018).

9. BBC. (2013). Tailandia, el primer país que prohíbe la moneda virtual Bitcoin. Recuperado de https://www.bbc.com/mundo/ultimas_noticias/2013/07/130730_ultnot_bitcoin_tailandia_vp

10. Bit2me Academy. (2020). ¿Qué son las altcoins y qué ofrecen a Bitcoin?. Recuperado de https://academy.bit2me.com/que-sonlas-altcoins/

11. Bitcoin History: The Complete History of Bitcoin [Timeline]. (2014). Recuperado de http://historyofbitcoin.org/

12. Bitpanda. (2020). What are mining pools and how do they work? Recuperado de https://www.bitpanda.com/academy/en/lessons/what-is-the-purpose-of-mining-pools-and-how-do-they-work/

13. Blockchain. (2020). Cost-per-transaction. Recuperado de https://www.blockchain.com/charts/cost-per-transaction

14. Briere, M., Oosterlinck, K., \&Szafarz, A. (2015). Virtual currency, tangible return: Portfolio diversification with bitcoin. Journal of Asset Management, 16(6), 365-373.

15. BuyBitcoinWorldwide. (2020). ¿Cuántos Bitcoinshay?. Recuperado de https://www.buybitcoinworldwide.com/es/cuantosbitcoins-hay/ 
16. Cabanes, A. M. (2017). Lo que hay que saber sobre el bitcoin: otras criptomonedas.

17. Canóvas Vaca, P. (2014). BITCOIN: una alternativa fallida al sistema monetario centralizado.

18. Cárdenas, Z. J. P., Avellaneda, M. A. V., \& Bermúdez, G. M. T. (2015). Bitcoin como alternativa transversal de intercambio monetario en la Economía Digital. Redes de Ingeniería, 6(1), 106-128

19. Carrillo Padrón, A. D. (2019). Análisis de datos del Bitcoin.

20. Casares, M. (2019). Minería de Bitcoin en Tierra del Fuego.

21. Castro, G. (2019). ¿Cómo detectar a tiempo un correo fraudulento y evitar un robo electrónico? Recuperado de https://www.bbva.com/es/sepa-como-detectar-a-tiempo-un-correo-fraudulento/

22. Chainalysis. (2018). Recuperado de https://chainalysis-blog.webflow.io/

23. Chohan, U. W. (2017). A history of bitcoin. Available at SSRN 3047875.

24. Cointelegraph. (2018). ¿Qué es Ripple? Todo lo que necesitas saber. Recuperado de https://es.cointelegraph.com/ripple101/what-is-ripple

25. ConesaLareo, C. (2019). Bitcoin: ¿una solución para los sistemas de pago o una solución en busca de problema? Documentosocasionales/Banco de España, 1901.

26. Conti, A. (2017). Bitcoin (Doctoral dissertation, Universidad Nacional de Cuyo. Facultad de CienciasEconómicas).

27. Cotte, J., \& Latour, K. A. (2009). Blackjack in the kitchen: Understanding online versus casino gambling. Journal of Consumer Research, 35(5), 742-758.

28. Covarrubias, J. Z. L., \& Covarrubias, I. N. L. (2019) Democracia tecnológica

29. De Biase, P., \& Mayor, D. J. (2017). Estudio sobre una nueva forma de financiación en la era digital.

30. Deloitte. (2017). La revolución del Blockchain en la Auditoría Interna. Recuperado de https://www2.deloitte.com/es/es/pages/governance-risk-and-compliance/articles/blockchain-auditoria-interna.html

31. Díaz, Z. E. (2020). Historia de Bitcoin. Recuperado de https://www.ig.com/es/estrategias-de-trading/historia-de-bitcoin190910

32. Duffield, E., \& Hagan, K. (2014). Darkcoin: Peertopeer cryptocurrency with anonymous blockchain transactions and an improved proofofwork system. bitpaper. info.

33. EFE. (2016). Japón considerará al Bitcoin como divisa para fomentar su uso y su seguridad. Recuperado de https://www.efe.com/efe/america/economia/japon-considerara-al-bitcoin-como-divisa-para-fomentar-su-uso-yseguridad/20000011-2848609

34. European Banking Authority. (2014). EBA Opinion on 'virtual currencies'.

35. Fabozzi, F. J., \& Jones, F. J. (2019). Foundations of Global Financial Markets and Institutions. MIT Press.

36. Falk, T., \&Falk, T. (2020). 6 de las mejores carteras de hardware 2020. Recuperado de https://www.finder.com/mx/mejorescarteras-hardware-para-criptomonedas

37. Fonseca, F. D. O. D., Santiago, M. R., \&Amorín, M. (2019). Criptomonedas: un dialogo necesario entre el sistema monetario actual y el desarrollo sustentable. RevistaBrasileira de Direito, 15(2), 5-29.

38. Forero Gonzales, M., \& Sanabria de Luque, J. (2017). Ventajas y desventajas de la aplicación de las criptomonedas "bitcoin" 
en el ordenamiento juridico-tributario de colombia (Doctoral dissertation, Universidad del Magdalena).

39. Frankenfield, J. (2019). Initial Coin Offering (ICO). Recuperado de https://www.investopedia.com/terms/i/initial-coinoffering-ico.asp

40. García Alejo, L. A. (2016). Bitcoin: Documentos electrónicos para el intercambio de bienes y servicios.

41. García Rodrigo, R. (2017). Bitcoin, ¿una criptodivisa rentable?

42. González, I. A. P. (2018). Criptomonedas: naturaleza jurídica y riesgos en la regulación de su comercialización. Revista de derecho del mercado de valores, (22), 5.

43. Gorjón, S. (2014). Divisas o Monedas Virtual: El caso de Bitcoin.

44. Gronwald, Marc. (2019). Another Look at Cryptocurrency Bubbles.

45. Gupta, G., Bansal, R., \&Porwal, P. S. (2019). Blockchain and Bitcoin. Business Management and Social Innovations, 411.

46. Gútierrez, F. M. (2015). Burbuja especulativa. Recuperado de https://www.expansion.com/diccionario-economico/burbujaespeculativa.html

47. Gutiérrez, O., \& Moreno, A. (2017). El bitcoin: consideraciones financieras y legales sobre su naturaleza y propuesta de enfoque para su regulación. Universidad ESAN.

48. Haggard, S., Maxfield, S., \& Lee, C. H. (Eds.). (2019). The politics of finance in developing countries. Cornell University Press.

49. Herman, A. (2014). The Economics of Bitcoin. Durham University, Thesis.

50. Herrera, P. E. L., \& Hernández, R. M. (2018). Bitcoin, Moneda de Nueva Generación, Implicaciones para la Sociedad y Negocios. Ma. de Lourdes Martínez Cerda William F. Valdivia Altamirano, 154.

51. Hileman, Garrick \&Rauchs Michel. (2017). Global Cryptocurrency Benchmarking Study (2017).

52. Hill, K. (2013). Federal Judge Rules Bitcoin Is Real Money. Recuperado de https://www.forbes.com/sites/kashmirhill/2013/08/07/federal-judge-rules-bitcoin-is-real-money/\#30666f2d27b8

53. Howlett, M. (2019). Designing public policies: Principles and instruments. Routledge.

54. Hume, T. (2013). How the FBI caught Ross Ulbricht, alleged creator of Silk Road. Recuperado de https://edition.cnn.com/2013/10/04/world/americas/silk-road-ross-ulbricht/

55. IG. (2020). Bitcoin halving. Recuperado de https://www.ig.com/es/bitcoin/bitcoin-halving

56. Johnson, B., Laszka, A., Grossklags, J., Vasek, M., \& Moore, T. (2014, March). Game-theoretic analysis of DDoS attacks against Bitcoin mining pools. In International Conference on Financial Cryptography and Data Security (pp. 72-86). Springer, Berlin, Heidelberg.

57. Johnston, D., Yilmaz, S. O., Kandah, J., Bentenitis, N., Hashemi, F., Gross, R.,... \& Mason, S. (2014). The General Theory of Decen-tralized Applications, DApps.

58. Konoth, R. K., Vineti, E., Moonsamy, V., Lindorfer, M., Kruegel, C., Bos, H., \& Vigna, G. (2018, January). Minesweeper: An in-depth look into drive-by cryptocurrency mining and its defense. In Proceedings of the 2018 ACM SIGSAC Conference on Computer and Communications Security (pp. 1714-1730).

59. Kostakis, V., \&Giotitsas, C. (2014). The (A) political economy of bitcoin. Triple C: Communication, Capitalism \& Critique. Open Access Journal for a Global Sustainable Information Society, 12(2), 431-440. 
60. Lane, E. (2018). Por qué Islandia se convirtió en el lugar con más "minas" de criptomonedas del mundo. Recuperado de https://www.bbc.com/mundo/vert-cap-44737892

61. Lemon, A. (2017). ¿Bitcoin Está en una Burbuja? Recuperado de https://es.dailyforex.com/forex-articles/2017/06/bitcoin-estáen-una-burbuja-26-de-junio-2017/80981

62. Lesemann, M. (2020). Is Bitcoin Legal? Recuperado de https://www.investopedia.com/ask/answers/121515/bitcoin-legalus.asp

63. Ludwig, S. (2013). Y combinator-backed coinbase now selling over $\$ 1$ m bitcoin per month, venture beat.

64. Macho Rojas, Á. (2019). Tecnología Blockchain y criptomonedas.

65. Madrid, A. (2019) Bitcoin 2019: ¿cuánta gente en el mundo lo usa realmente? -. Recuperado de https://bitcoin.es/actualidad/cuanta-gente-usa-bitcoin-en-2019/

66. Marco, S. F. J. (2017). Altcoin (criptomoneda) - Definición, qué es y concepto. Recuperado de https://economipedia.com/definiciones/altcoin-criptomoneda.html

67. Marrero Travieso, Y. (2003). La Criptografía como elemento de la seguridad informática. Acimed, 11(6), 0-0.

68. Martin, A., \& Pons, M. À. (2019). Bitcoin:¿ La moneda del futuro?. Quaderns IAFI, (1).

69. McLeod, S. (2017). Bitcoin: The utopia or nightmare of regulation. Elon L. Rev., 9, 553.

70. Medina Reyes, M. F. (2016). Análisis y comparación de monedas criptográficas basadas en la tecnología Blockchain.

71. Meynkhard, A. (2019). Fair market value of bitcoin: halving effect. Investment Management \& Financial Innovations, 16(4), 72.

72. Miranda Palacios, V. (2018). Explorando la Blockchain de Ethereum y el desarrollo de smartcontracts (Bachelor'sthesis, UniversitatPolitècnica de Catalunya).

73. Nakamoto, S. (2008). Bitcoin: A peer-to-peer electronic cash system. Manubot.

74. Navarro, B. Y. (2017). Blockchain y sus aplicaciones. Universidad Católica Nuestra Señora de La Asunción.

75. Nawaz, Z., Sajid, A., Anwar, S., \& Khalid, H. (2019). Review Paper on Bitcoin Technology. Information Management and Computer Science (IMCS), 2(2), 01-03.

76. Nayfack, N. G. (2019). U.S. Patent No. 10,438,177. Washington, DC: U.S. Patent and Trademark Office.

77. New York Press. (2015). NYDFS Announces Approval of First Bitlicense Application From a Virtual Currency Firm. Recuperado de https://www.dfs.ny.gov/reports_and_publications/press_releases/pr1509221

78. Newcomb, A. (2014). Bitcoin Pizza Day: Why 2 pies are now worth 4\% million. Recuperado de https://abcnews.go.com/Technology/bitcoin-pizza-day-pies-now-worth-million/story?id=23824128

79. Oregaen, A., Fabiana, E., Priori, M. B., \&Ruzak, A. A. (2014). Bitcoin: la moneda alternativa (Doctoral dissertation, Universidad Argentina de la Empresa).

80. Pallares, R. (2014). ¿Son las monedas virtuales el futuro de las finanzas internacionales? Recuperado el, 18.

81. Pérez Solà, C., \& Herrera Joancomartí, J. (2014). Bitcoins y el problema de los generales bizantinos.

82. Plus500. (2020). ¿Cuáles son las criptomonedas más negociadas? Recuperado de https://www.plus500.es/Trading/CryptoCurrencies/What-are-the-Most-Traded-Cryptocurrencies 2 
83. Preukschat, A. (2016). Blockchain. La revolución industrial de internet. Obtenido de https://www. academia. edu/36701339/Blockchain._La_revoluci\% C3\% B3n_industrial_de_internet_-_Alexander_Preukschat.

84. Rabasa Martínez, I. (2017). El uso de bitcoins en las plataformas de crowdfunding.

85. Ramos Taboada, F. (2014). Bitcoinomics: ¿ puede un sistema bancario de reservas fraccionarias funcionar dentro de la comunidad Bitcoin?.

86. Redman, J. (2016). Uber Thriving in Argentina Once Again Thanks to Bitcoin. Recuperado de https://news.bitcoin.com/uberthriving-argentina-bitcoin/

87. Reiff, N. (2020). Bitcoin vs. Bitcoin Cash: What Is the Difference? Recuperado de https://www.investopedia.com/tech/bitcoinvs-bitcoin-cash-whats-differencel

88. Reiff, N. (2020). The 10 Most Important Cryptocurrencies Other Than Bitcoin. Recuperado de https://www.investopedia.com/tech/most-important-cryptocurrencies-other-than-bitcoin/

89. Retamal, C. D., Roig, J. B., \& Tapia, J. L. M. (2017). La blockchain: fundamentos, aplicaciones y relación con otras tecnologías disruptivas. Economía industrial, 405, 33-40.

90. Reuters (2013). EEUU cierra Silk Road, un mercado negro de armas y drogas en la red. Recuperado de https://www.elmundo.es/america/2013/10/02/estados_unidos/1380737961.html

91. Ricaurte Cely, S. P., \& Romero Calderón, J. D. (2018). Bitcoin, impedimentos legales que afectan una implementación, en un sistema económico como el colombiano.

92. Ripple. (2020). Our Story: About Ripple. Recuperado de https://ripple.com/company

93. Riquelme, $R$. (2017). ¿Cuáles son las regulaciones del bitcoin en el mundo? Recuperado de https://www.eleconomista.com.mx/listas/Cuales-son-las-regulaciones-del-bitcoin-en-el-mundo-t201710040003.html\#item-6

94. Romero Ugarte, J. L. (2018). Tecnología de registros distribuidos (DLT): una introducción. Boletíneconómico/Banco de España [Artículos], n. 4, 2018, 12 p.

95. Rosales, M. S., Maledo, V. G. R., \&Garcia, G. G. (2017) Bitcoin: Una visión general.

96. Rosenfeld, M. (2017). Predicting Block Halving Party Times. arXiv preprint arXiv:1708.05185.

97. Sánchez Ascanio, L. C., \& Arredondo García, J. A. (2020). Predicting the Price of Bitcoin, and more. Suma de Negocios, $11(24), 42-52$.

98. Sánchez J. M. (2017). La década (tecnológica) prodigiosa que giró por completo al planeta. Recuperado de https://www.abc.es/tecnologia/informatica/soluciones/abci-decada-tecnologica-prodigiosa-giro-completo-planeta201712202217 noticia.html

99. Sánchez, J. (2020) Burbuja económica - Definición, qué es y concepto. Recuperado de https://economipedia.com/definiciones/burbuja-economica.html

100. Sanjuán, A., \& Costa, S. M. (2019). Publicidad y marketing móvil: el auge de las compras online. In Comunicaciónmóvil (pp. 199-218). Editorial UOC.

101. Saravia, M., Javiel, J., \& Paredes, F. (2018). Análisis y evaluación de ataques a pools de minería en bitcoin.

102. Schollmeier, R. (2001, August). A definition of peer-to-peer networking for the classification of peer-to-peer architectures and applications. In Proceedings First International Conference on Peer-to-Peer Computing (pp. 101-102). IEEE. 
103. Segendorf, B. (2014). What is bitcoin? Sverigesriksbank economic review.

104. SevillejaFebrer, J. (2013). Bitcoin y malware, ¿un nuevo modelo de negocio?.

105. Solís, S. M. (2016). Bitcoin. Guía completa de la moneda del futuro. Grupo Editorial RA-MA.

106. Su, J. (2018). Blockchain y las criptomonedas actuales.

107. Suárez, J. E. S., \& Bautista, J. L. G. (2016). Criptodivisas en el entorno global y su incidencia en Colombia. RevistaLebret, (8), 151-171.

108. Tejada Manrique, C. R. (2014). ¿Es el Bitcoin una alternativa a los medios de pago tradicionales?

109. Tostado, O. A., González, M. D. C. O., Burgueño, A. M. D., \& Ramírez, I. T. (2017). Análisis de riesgo económico al implementar la moneda virtual bitcoin como moneda complementaria en méxico. Revista Digital de Tecnologías Informáticas y Sistemas, 1(1).

110. Vargas Aguirre, G. A., \& Díaz Flores, M. (2016). Las crisis financieras y la evolución del paradigma en la práctica de las finanzas. Semestre Económico, 19(40), 53-70.

111. Vergara Solís, M. A. (2017). Retos para las autoridades reguladoras y de control frente a la utilización del bitcoin como medio de pago electrónico (Master's thesis, Universidad Andina Simón Bolívar, Sede Ecuador).

112. Wagner, K. (2013). World's First Bitcoin ATM Opens In Vancouver, Canada. Recuperado de https://mashable.com/2013/10/30/bitcoin-atm-2/?europe $=$ true

113. Wander, M. (2011). How Bitcoin Works.

114. Watkins, D. (2017). Scrypt Mining with ASICs.

115. Yermack, D. (2015). Is Bitcoin a real currency? An economic appraisal. In Handbook of digital currency (pp. 31-43). Academic Press.

116. Yuzvovich, L. I., Isakova, N. Y., \& Mokeeva, N. N. (2019). Bitcoin financial bubbles: digitalization and modeling. In 1st International Scientific Conference" Modern Management Trends and the Digital Economy: from Regional Development to Global Economic Growth"(MTDE 2019). Atlantis Press.

117. Zapiola Guerrico, M. (2019). El impacto de las nuevas tecnologías en la actividad aseguradora. Ed. La Ley, Buenos Aires, Argentina. 
